\title{
Hepatitis B Core Antigen in Hepatocytes of Chronic Hepatitis B: Comparison between Indirect Immunofluorescence and Immunoperoxidase Method
}

\author{
1,2 Ruksana Raihan, ${ }^{1}$ Shahina Tabassum, ${ }^{3}$ Mamun Al-Mahtab, ${ }^{2}$ Afzalun Nessa, ${ }^{2}$ Munira Jahan \\ ${ }^{4}$ Chowdhury Mohammad Shamim Kabir, ${ }^{5}$ Mohammad Kamal, ${ }^{6}$ Julio Cesar Aguilar
}

\begin{abstract}
Background: Hepatitis B virus (HBV) infection has many faces. Precore and core promoter mutants resemble inactive carrier status. The identification of hepatitis $B$ core antigen $(\mathrm{HBcAg})$ in hepatocytes may have variable clinical significance. The present study was undertaken to detect HBcAg in chronic hepatitis B (CHB) patients and to assess the efficacy of detection system by indirect immunofluorescence (IIF) and indirect immunoperoxidase (IIP).
\end{abstract}

Materials and methods: The study was done in 70 chronic HBV-infected patients. Out of 70 patients, eight (11.4\%) were hepatitis B e antigen $(\mathrm{HBeAg})$ positive and $62(88.57 \%)$ were $\mathrm{HBeAg}$ negative. Hepatitis $B$ core antigen was detected by indirect immunofluorescence (IIF) and indirect immunoperoxidase (IIP) methods in liver tissue.

Results: All HBeAg positive patients expressed HBcAg by both IIF and IIP methods. Out of 62 patients with HBeAg-negative CHB, HBcAg was detected by IIF in $55(88.7 \%)$ patients and by IIP in 51 (82.26\%) patients. A positive relation among viral load and HBcAg detection was also found. This was more evident in the case of $\mathrm{HBeAg}$ negative patients and showed a positive relation with HBV DNA levels.

Conclusion: Hepatitis B core antigen can be detected using the IIF from formalin fixed paraffin block preparation and also by IIP method. This seems to reflect the magnitudes of HBV replication in CHB.

Keywords: Chronic hepatitis B infection, Hepatitis B core antigen, Indirect immunofluorescence, Indirect immunoperoxidase.

How to cite this article: Raihan R, Tabassum S, Al-Mahtab M, Nessa A, Jahan M, Kabir CMS, Kamal M, Aguilar JC. Hepatitis B Core Antigen in Hepatocytes of Chronic Hepatitis B: Comparison between Indirect Immunofluorescence and Immunoperoxidase Method. Euroasian J HepatoGastroenterol 2015;5(1):7-10.

Source of support: Nil

Conflict of interest: None

\section{INTRODUCTION}

Globally, hepatitis B virus (HBV) is one of the most common infectious diseases and the major cause of chronic hepatitis, cirrhosis, and hepatocellular carcinoma (HCC) ${ }^{1-4}$ Bangladesh is a densely populated country with intermediate endemicity (2 to $7 \%$ ) for chronic hepatitis B (CHB), where the lifetime risk of acquiring $\mathrm{HBV}$ infection is between up to $60 \% .{ }^{5}$ Various studies from Bangladesh have shown that $\mathrm{HBV}$ is responsible for $31.25 \%$ cases of acute hepatitis, $76.3 \%$ cases of chronic hepatitis, $61.15 \%$ cases of cirrhosis of liver and $33.3 \%$ cases of HCC. ${ }^{6-8}$

\footnotetext{
${ }^{1}$ Department of Microbiology, Faculty of Medicine, AIMST University, Bedong, Kedah, Malaysia

${ }^{2}$ Department of Virology, Bangabandhu Sheikh Mujib Medical University, Shahbag, Dhaka, Bangladesh

${ }^{3}$ Department of Hepatology, Bangabandhu Sheikh Mujib Medical University, Shahbag, Dhaka, Bangladesh

${ }^{4}$ Department of Medicine, Shaheed Suhrawardy Medical College and Hospital, Mirpur, Dhaka, Bangladesh

${ }^{5}$ Department of Pathology, Bangabandhu Sheikh Mujib Medical University, Shahbag, Dhaka, Bangladesh

${ }^{6}$ Department of Biomedical Research, Centre for Genetic Engineering and Biotechnology, Havana City, Cuba
}

Address reprint requests to: Ruksana Raihan, Lecturer, Department of Microbiology, Faculty of Medicine, AIMST University, Bedong Kedah, Malaysia, Phone: +8801713338008, e-mail: shathi16@yahoo.com 
Hepatits B virus is a $42 \mathrm{~nm}$ particle. The major antigens comprising $\mathrm{HBV}$ are the hepatitis $\mathrm{B}$ surface antigen (HBsAg) and the hepatitis B core antigen ( $\mathrm{HBcAg})$. A secreted variant of the nucleocapside antigen, the hepatitis B e antigen (HBeAg) can be detected in the blood. However, $\mathrm{HBcAg}$ is only detectable in the hepatocytes, both in nucleus or cytoplasm. ${ }^{9}$ Presence of $\mathrm{HBcAg}$ in hepatocyte is related to the presence of $\mathrm{HBeAg}$ as a marker of HBV replication. However, a significant proportion of patients with $\mathrm{CHB}$ are infected with the mutant $\mathrm{HBV}$ which decreases or abolishes the production of HBeAg due to mutation of precore or core promoter region. ${ }^{10,11}$ Such variants, called $\mathrm{HBeAg}$ negative $\mathrm{CHB}$, they are commonly found in Mediterranean and Asian countries. ${ }^{10}$ Detection of circulating HBV DNA and HBcAg in liver tissues may be an indicator of active viral replication compared to HBeAg. ${ }^{11,12}$ Both indirect immunofluorescence (IIF) and indirect immunoperoxidase (IIP) can be used to detect $\mathrm{HBcAg}$ in hepatocytes. In the present study, we applied both methods for the detection of HBcAg in hepatocytes and compared their expressions in formalin fixed and paraffin-embedded liver tissue of $\mathrm{CHB}$ patients.

\section{MATERIALS AND METHODS}

\section{Study Design}

This cross-sectional study was carried out among 70 patients who were incidentally diagnosed as $\mathrm{CHB}$ patients and underwent liver biopsy as part of their routine clinical management.

\section{Subjects}

Patients were selected from the Inpatient Department of Hepatology, Bangabandhu Sheikh Mujib Medical University (BSMMU) Hospital, Dhaka, Bangladesh, and laboratory works were performed at the Department of Virology of BSMMU. Patients were expressing HBsAg for at least 6 months with serum HBeAg positive or negative and had detectable serum HBV DNA. Patients gave written consent for the study. Patients with the history of significant alcohol consumption (> $20 \mathrm{gm} /$ day), renal disease, heart disease or malignancy, and with detectable antibodies to human immunodeficiency virus (HIV) and hepatitis $\mathrm{C}$ virus (HCV), history of previous antiviral treatment were excluded from the study.

\section{Sample Collection}

Under all aseptic precautions, a trucut liver biopsy was done by a hepatologist. The tissues were fixed in formalin and embedded in paraffin for routine histological study and for IIF staining and indirect IIP staining.

\section{Staining Procedure}

Five micrometer thick tissue sections from paraffin blocks were taken on albumin coated slides and incubated at $37^{\circ} \mathrm{C}$ overnight for 16 hours. Then, after deparaffinization intrahepatic expression of $\mathrm{HBcAg}$ were studied by using polyclonal rabbit anti-HBcAg (Dako, Carpinteria, CA, USA) as primary antibody and the color reaction was enhanced by Envision Detection Kit (Dako) from formalin fixed paraffin embedded tissues for immunoperoxidase method. Immunofluorescence staining was done by fluorescein isothiocyanate conjugated secondary antibody (Polyclonal Swine Anti-Rabbit Immunoglobulin/FITC, Dako). The amount of HBcAg in liver was also semiquantitatively scored according to the proportion of hepatocytes that stained positive on a 0 to $3+$ scale ( $0 \%$ - absent, 1 to $10 \%$ - grade 1,11 to $50 \%$ - grade 2, > $50 \%$ - grade 3). ${ }^{13}$ Intra-cellular localization of $\mathrm{HBcAg}$ was labeled as nuclear, cytoplasmic or mixed type (mixed but predominantly nuclear and mixed but predominantly cytoplasmic).

\section{Other Methods}

Virological (HBV DNA) and serological (serum HBsAg and $\mathrm{HBeAg}$ ) tests were conducted at Labaid Hospital, Dhaka, by conventional methods.

\section{STATISTICAL ANALYSIS}

Statistical analysis was done by Prism Software, version 4 . Results were expressed as percentage, mean and standard deviation. For comparison between two methods, Kappa statistic of agreement test and validity test were done.

\section{RESULTS}

The present study was carried out among 70 serologically diagnosed $\mathrm{CHB}$ patients. Out of total 70 patients, 58 were males and 12 were females with a mean age of 30.51 years.

All eight patients (11.43\%) that were HBeAg positive expressed HBcAg in the liver (Table 1). However, 55 of 62 patients $\mathrm{HBeAg}$ negative cases expressed $\mathrm{HBcAg}$ by IIF method and 51 of 62 patients showed $\mathrm{HBcAg}$ in the liver by IIP method.

Table 1: Relation of HBcAg and HBV DNA according to HBeAg status of patients

\begin{tabular}{lllll}
\hline & \multirow{2}{*}{$\begin{array}{l}\text { DNA } \\
\text { (copies/ml) }\end{array}$} & \multicolumn{2}{c}{$H$ HBcAg by IIF } & \\
\cline { 3 - 4 } HBe $A g$ & Positive & Negative & Total \\
\hline $\begin{array}{l}\text { Positive } \\
(\mathrm{n}=8)\end{array}$ & $\geq 10^{5}$ & $8(100.0)^{\#}$ & - & $8(100.0)$ \\
$\begin{array}{l}\text { Negative } \\
(\mathrm{n}=55)\end{array}$ & $<10^{5}$ & $37(67.3)$ & $5(71.4)$ & $42(67.7)$ \\
& $\geq 10^{5}$ & $18(32.7)$ & $2(28.6)$ & $20(32.3)$
\end{tabular}

\#Figure within parentheses indicates in percentage 
The HBV DNA profile of the study patients were categorized into high $\left(\geq 10^{5}\right.$ copies $\left./ \mathrm{ml}\right)$ and low $\left(<10^{5}\right.$ copies/ $\mathrm{ml})$. All eight $(100 \%)$ patients who were $\mathrm{HBeAg}$ positive had high levels of HBV DNA. Among HBeAg negative and $\mathrm{HBcAg}$-expressing patients, 37 (67.3\%) had low HBV DNA $\left(<10^{5}\right.$ copies $\left./ \mathrm{ml}\right)$, while $18(32.7 \%)$ patients had high circulating HBV DNA $\left(\geq 10^{5}\right.$ copies/ml). Among the seven cases with $\mathrm{HBeAg}$-positive and $\mathrm{HBcAg-negative,}$ five (71.4\%) had low HBV DNA and two (28.6\%) had high HBV DNA (Table 1). Most (7 out of 8) HBeAg positive patients had grade $3 \mathrm{HBcAg}$ with a mean HBV DNA of $1.2 \times 10^{11} \pm 3.3 \times 10^{11}$ copies $/ \mathrm{ml}$. The patient classified as grade 1 had a comparatively low HBV DNA load $(6.4 \times$ $10^{6}$ copies $\left./ \mathrm{ml}\right)$.

The levels of HBV DNA in patients with grades 1, 2 and 3 expression of $\mathrm{HBCAg}$ in the liver were $1.6 \times 10^{4} \pm$ $1.88 \times 10^{4}$ copies $/ \mathrm{ml}, 1.36 \times 10^{7} \pm 7.35 \times 10^{7}$ copies $/ \mathrm{ml}$, $1.6 \times 10^{10} \pm 5.87 \times 10^{10}$ copies $/ \mathrm{ml}$ respectively. There was no statistical differences among grades 1, 2 and none groups but there was a significant difference in grade 3 and 2, grade 3 and none $(p<0.05)$, between grade 3 and $1(\mathrm{p}<0.01)($ Graph 1$)$.

Out of 70 cases, 59 were positive for $\mathrm{HBcAg}$ by both IIP and indirect IIF methods. Eleven cases were negative for core antigen by IIP method, among which seven were negative by both the methods, but four of this 11 were positive in IIF methods. Validity test showed that sensitivity of IIF was $100 \%$, specificity was $63.6 \%$ and accuracy was $94.3 \%$.

\section{DISCUSSION}

The detection of $\mathrm{HBcAg}$ in liver biopsy samples from Bangladeshi CHB patients explored the antigen expression and their relation to virological variables using two staining methods. Previous studies showed that HBeAg positive $\mathrm{CHB}$ patients have higher serum HBV DNA

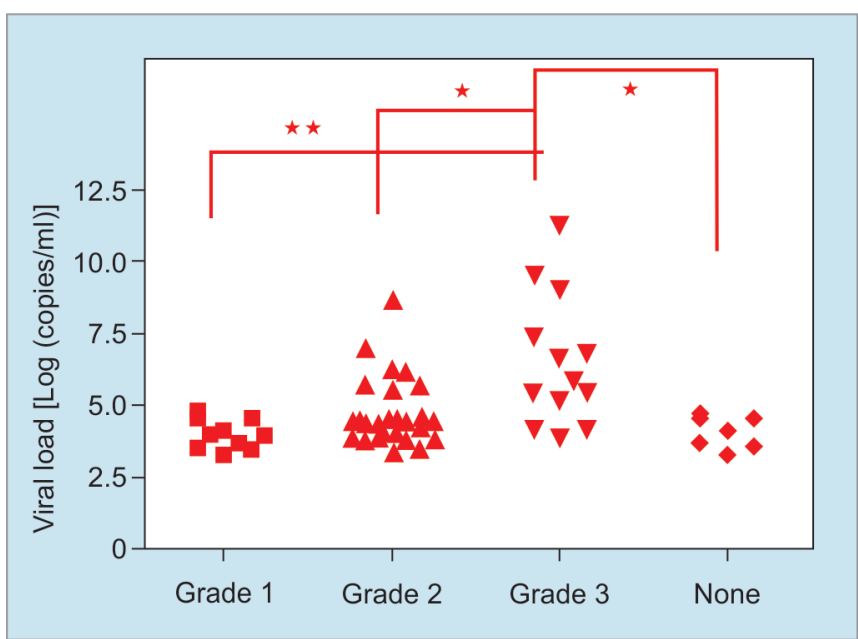

Graph 1: Relation between the HBV DNA load and the HBcAg grade among HBeAg negative patients $\left({ }^{* *} p<0.01\right.$; $\left.{ }^{*} p<0.05\right)$ levels than HBeAg negative patients. ${ }^{14-16} \mathrm{All} \mathrm{HBeAg}$ positive cases were positive for $\mathrm{HBcAg}$ in hepatocytes. This result was similar with a study from Taiwan which found $100 \%$ of HBcAg expression in hepatocytes among HBeAg positive patients. ${ }^{17}$ A study conducted in Korea also observed high prevalence $(92 \%)$ in this group of patients. ${ }^{13}$

Interestingly, among $\mathrm{HBeAg}$ negative cases, a very high percentage of patients (88.7\%) were HBcAg positive in hepatocytes compared to reporting from Asia, were the HBcAg detection was $59 \%$ in Korea. ${ }^{13,17}$ It would be important to examine in the future the influence of regional HBV genotypes in the $\mathrm{HBcAg}$ hepatocytes expression. Present results were further confirmed by IIF in more than $90 \%$ of the samples to avoid any technique related variability. ${ }^{18}$

Only with one exception, all $\mathrm{HBeAg}$ positive patients were classified as grade 3 according to $\mathrm{HBcAg}$ level in hepatocytes. Hence, it was not possible to establish a relation between viral load and $\mathrm{HBCAg}$ grade. However, for HBeAg negative cases, it was found a more homogeneous distribution among grades. In such patients, the increase in the grade of $\mathrm{HBcAg}$ detection in hepatocytes was related to the increase of HBV DNA, suggesting that grading $\mathrm{HBcAg}$ expression in hepatocytes may be a useful marker for replication in case of HBeAg negative patients. Thus, liver biopsy results could be complemented with further virological information, increasing the value of this aggressive procedure. The detection of $\mathrm{HBcAg}$ in hepatocytes has been considered a marker of active replication. ${ }^{19}$

The finding of disease progression in patients with low-viral load among patients with HBeAg negative serology in Bangladesh remains a matter of concern. ${ }^{20}$ Other countries have referred similar results. ${ }^{21,22}$ This particular variable- $\mathrm{HBcAg}$ grade-could provide important information in these patients as serum HBV DNA fluctuates in HBeAg negative patients and the decision to start treatment is a complex issue nowadays. ${ }^{23,24}$ Both IIF and IIP tests were performed in the present study to detect HBV core antigen. According to the performance and agreement tests, IIF was found to be an alternative to the IIP method. Although IIP method is a well-accepted and well-practiced method throughout the world, it is costly and needs very skilled hands from the technical point of view. In contrast, IIF method is costeffective, less time consuming and more user-friendly. Therefore, IIF maybe used as an alternative to IIP method.

\section{ACKNOWLEDGMENT}

Bangabandhu Sheikh Mujib Medical University (BSM$\mathrm{MU})$ has sponsored the study. We acknowledge the help extended by all the staff of the Department of Virology, 
BSMMU, Dhaka. We are also grateful to all the CHB patients included in this study.

\section{REFERENCES}

1. Mehedi SR, Pophali A, Al- Abdul Rahim KA. Prevalence of hepatitis B and C and blood donors. Saudi Med J 2000;21: 942-944.

2. Wright TL. Introduction to chronic hepatitis B infection. Am J Gastroenterol 2006;101(s1):S1-S6.

3. Hou J, Liu Z, Gu F. Epidemiology and prevention of hepatitis B virus infection. Int J Med Sci 2005;2(1):50-57.

4. Mericam I, Guan R, Amarapuka D, et al. Chronic hepatitis B virus infection in Asian countries. J Gastroenterol Hepatol 2000;15(12):1356-1361.

5. Mahtab MA, Rahmna S, Akbar SM, Kamal M, Khan MS. Clinical use of liver biopsy for the diagnosis and management of inactive and asymptomatic hepatitis B virus carriers in Bangladesh. J Med Virol 2010;82:1350-1354.

6. Khan M, Zaki KMJ, Ahmed KU. Clinical profile: Prognostic index in hepatocellular carcinoma. Bangladesh Med Res Bull 1991;XVII:49-62.

7. Afroz S, Mahtab MA, Rahman S, Khan M. Hepatitis B virus is the leading cause of cirrhosis of liver in Bangladesh. Hepatol Int 2007;1(1):120.

8. Alam S, Ahmed N, Mustafa G. Alam K, Khan M. Characteristics of treatment naïve chronic hepatitis B in Bangladesh: Younger populations are more affected: HBeAg-negatives are more advanced. Saudi J Gastroenterol 2008;14(1):15-19.

9. Jessica L, Verena S, Oliver S. Hepatology: A clinical text book 2009;5:59-61.

10. Funk ML, Rosenberg DM, Lok AS. World-wide epidemiology of HBeAg-negative chronic hepatitis B and associated precore and core promoter variants. J Viral Hepat 2002 Jan;9(1):52-61.

11. Lok ASF, McMahon BJ. Corrections to AASLD guidelines on chronic hepatitis B. Hepatol 2007;45(6):506-539.

12. Uzun Y, Bozkaya H, Erden E, Cinar K, et al. Hepatitis B core antigen expression pattern reflects the response to antiviral treatment. J Gastroenterol Hepatol 2006;21:977-981.

13. Kim TH, Cho EY, Oh HJ, et al. The Degree of Hepatocyte Cytoplasmic Expression of Hepatitis B Core Antigen correlates with Histologic Activity of Liver Disease in the Young
Patients with Chronic Hepatitis B Infection. J Korean Med Sci 2006 Apr;21(2):279-283.

14. Kao JH. Diagnosis of hepatitis B virus infection through serological and virological markers. Expert Rev Gastroenterol Hepatol 2008;2(4):553-562.

15. Pungpapong S, Kim WR, Poterucha JJ. Natural History of Hepatitis B Virus Infection: An Update for Clinicians. Mayo Clin Proc 2007;82(8):967-975.

16. Mellen JS, Xia VW, Hashemzadeh M, et al. The clinical presentation of chronic hepatitis B virus infection in Asian Americans: a single center retrospective study. J Clin Gastroenterol 2010;44(5):364-370.

17. Chu CM, Liaw YF. Membrane staining for hepatitis B surface antigen on hepatocytes: a sensitive and specific marker of active viral replication in hepatitis B. J Clin Pathol 1995;48(5): 470-473.

18. Raihan R, Tabassum S, Mahtab MA, et al. High HBcAg Expression in Hepatocytes of Chronic Hepatitis B Patents in Bangladesh. Euroasian Journal of Hepato-Gastroenterology 2012;2(2):63-69.

19. Chu CM, Liaw YF. Immunohistological study of intrahepatic expression of hepatitis B core and $\mathrm{E}$ antigens in chronic type B hepatitis. J Clin Pathol 1992;45(9):791-795.

20. Mahtab MA, Rahmna S, Akbar SM, Kamal M, Khan MS. Clinical Use of Liver Biopsy for the Diagnosis and Management of Inactive and asymptomatic Hepatitis B Virus Carriers in Bangladesh. J Med Virol 2010;82(8):1350-1354.

21. Akbar SM, Hiasa Y, Mishiro S, Onji M. Treatment of hepatitis $B$ virus-infected patients: utility of therapeutic recommendations in developing countries. Expert Opin Pharmacother 2009;10(10):1605-1614.

22. Wai CT, Mak B, Chua W, Lim SG. The majority of hepatitis B carriers are not on regular surveillance in Singapore. Singapore Med J 2004;45(9):423-426.

23. Papatheodoridis GV, Manolakopoulos S, Archimandritis AJ. Current treatment indications and strategies in chronic hepatitis B virus infection. World J Gastroenterol 2008;14(45): 6902-6910.

24. Papatheodoridis GV, Manesis EK, Manolakopoulos S, et al. Is there a meaningful serum hepatitis B virus DNA cutoff level for therapeutic decisions in hepatitis B e antigen-negative chronic hepatitis B virus infection? Hepatol 2008 Nov;48(5): 1451-1459. 